\title{
Growth characterization of CHO DP-12 cell lines with different high passage histories
}

\author{
Christoph Heinrich $^{1 *}$, Timo Wolf ${ }^{1}$, Christina Kropp ${ }^{1}$, Stefan Northoff ${ }^{2}$, Thomas Noll ${ }^{1}$ \\ From 22nd European Society for Animal Cell Technology (ESACT) Meeting on Cell Based Technologies \\ Vienna, Austria. 15-18 May 2011
}

\begin{abstract}
Introduction
For industrial pharmaceutical protein production fast growing, high producing and robust cell lines are required. To select $\mathrm{pH}$-shift permissive and faster growing sub-populations, the CHO DP-12 cell line was serially subcultured for more than four hundred days in shaker flasks. Initial adaptation to growth in suspension was carried out in chemically defined medium without hypoxanthine and thymidine (HT), while the final medium used for long term cultivation contains HT. Cell samples were cryopreserved at four different time points after 21, 95, 165 and 420 days. Cultivations of these four sub-populations (SP) in shaker flasks and bioreactors revealed considerable differences in specific growth rates and product formation as well as in the metabolism of glucose, lactate and several amino acids. For the elucidation of the intracelluar mechanism behind these alteration in growth characteristics and metabolism additional probes were analyzed using proteomic and metabolomic approaches [1].
\end{abstract}

\section{Material and methods}

In this study the CHO DP-12 clone\#1934 (ATCC CRL12445) was used as reference organism. It co-expresses the variable light and heavy chains of the murine 6G4.2.5 monoclonal antibody (ATCC-HB-11722) which inhibits binding of interleukin 8 to human neutrophile. CHO DP-12 cells were cultivated in CD-ACF medium TC 42 (TeutoCell AG) and PowerCHO-2 (LONZA AG) for the first steps of suspension adaptation. $200 \mathrm{nM}$ methotrexate was present at any time. Precultures and parallel cultivations were carried out in $125 \mathrm{~mL}$ and 250 $\mathrm{mL}$ polycarbonate Erlenmeyer flasks (Corning Life Sciences). Incubator conditions were set to $37^{\circ} \mathrm{C}, 5 \%$

\footnotetext{
* Correspondence: che@zellkult.techfak.uni-bielefeld.de

${ }^{1}$ Institute of Cell Culture Technology, Bielefeld University, Bielefeld, Germany Full list of author information is available at the end of the article
}

$\mathrm{CO}_{2}$ and relative humidity of $80 \%$. A shaker revolution of $185 \mathrm{rpm}$ or $125 \mathrm{rpm}$ with an orbital movement of 2" was chosen. For bioreactor cultivations four parallel vessels (Applikon) controlled by CellfermPro 2.3 software (DASGIP AG) were used. Cultivation parameters were set to $37^{\circ} \mathrm{C}, 40 \% \mathrm{DO}$ and $\mathrm{pH}$ 7.1.

Cell concentration and viability were determined with a CEDEX system (Innovatis-Roche AG). The anti IL-8 antibody was quantified using Protein A HPLC.

A MACSQuant ${ }^{\mathbb{B}}$ Analyzer (Miltenyi Biotec $\mathrm{GmbH}$ ) was used for the measurements of intracellular IgG-product pools. Intracellular detection of the antibodies required permeabilization of the cell membrane with detergents. IgG light and heavy chains were stained with fluorochrome-conjugated antibodies that bind to Fc and kappa chains of IgGs within fixed CHO cells (all solutions from Miltenyi Biotec $\mathrm{GmbH}$ ).

\section{Results}

The initial adaptation to growth in suspension of the CHO DP-12 cells led to considerable changes in average cell diameter and specific growth rate. Within the first 100 days of serial subculturing the cell diameter dropped from a maximum of about $17 \mu \mathrm{m}$ to $12 \mu \mathrm{m}$ as the lowest value. In the same period the cell specific growth rate increased from initially $0.2 \mathrm{~d}^{-1}$ up to values greater than $1.0 \mathrm{~d}^{-1}$. After further 320 days cells had an average diameter about $14 \pm 0.74 \mu \mathrm{m}$ and a mean specific growth rate of $0.82 \pm 0.12 \mathrm{~d}^{-1}$.

The growth characterizations of the four sub-populations SP21, SP95, SP165 and SP420 were carried out in several parallel controlled and uncontrolled batch cultivations. In addition to the influence of the insulin like growth factor 1 (IGF) the presence of hypoxanthine and thymidine (HT) was investigated as well. Most important characteristics for growth and productivity

C 2011 Heinrich et al; licensee BioMed Central Ltd. This is an open access article distributed under the terms of the Creative Commons Attribution License (http://creativecommons.org/licenses/by/2.0), which permits unrestricted use, distribution, and reproduction in any medium, provided the original work is properly cited. 


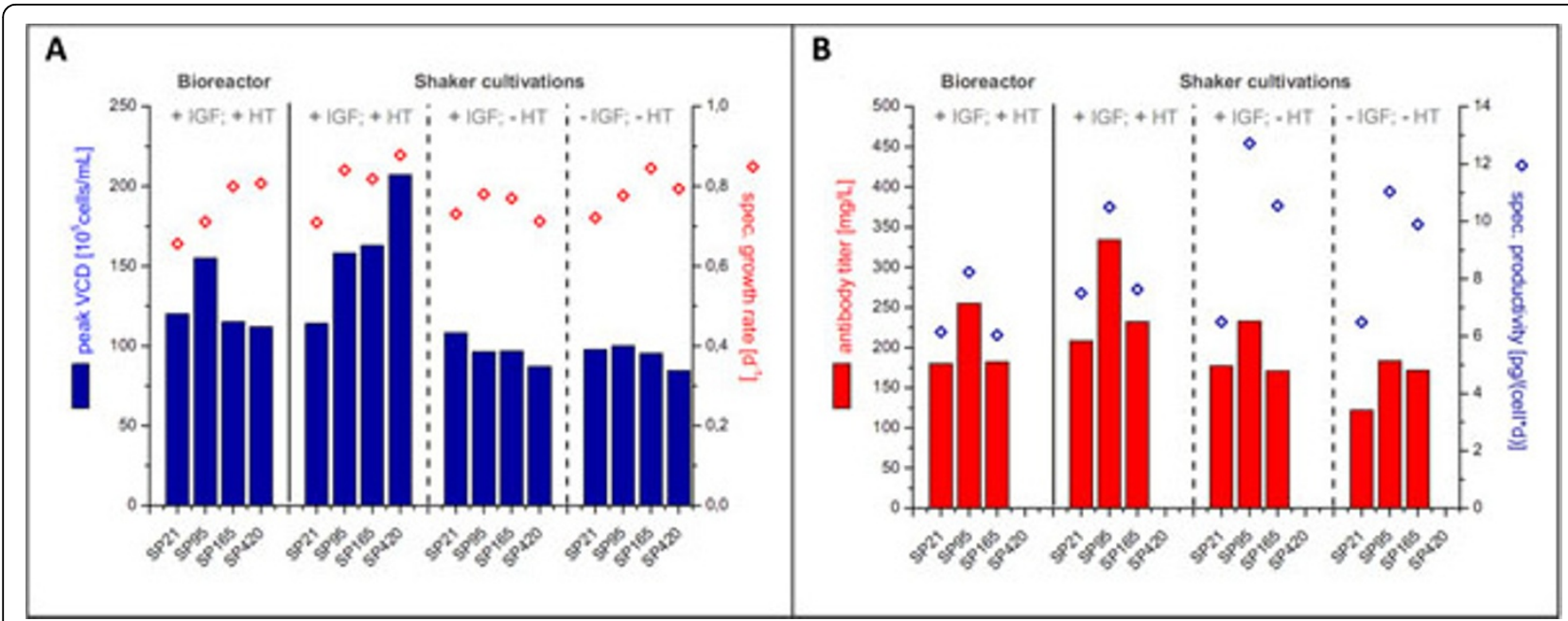

Figure 1 Overview of growth performance (A) and product formation (B) of the four sup-populations in controlled and uncontrolled culture systems with varying media supplementation.

determined in this experimental setup are presented in Figure 1.

Though the sub-populations SP95, SP165 and SP420 seemed to possess comparable growth rates in shake flask cultivations, they differed remarkably in their maximum cell density when HT-mix was present. For SP21 and SP420, maximum cell densities of about $1.1 \cdot 10^{7}$ cells $/ \mathrm{mL}$ and $2.1 \cdot 10^{7}$ cells $/ \mathrm{mL}$, respectively, were determined. These results indicate an influence of the HTmix on the maximum reachable cell densities. Furthermore, an increased passage number seemed to cause decreasing growth performance in the controlled bioreactor system compared to the results from the shake flask cultivations with HT containing medium. This fact could be associated to the adaptation of subcultivated cells to $\mathrm{pH}$-shifts that occur during cultivation under uncontrolled conditions. Additionally, the observed differences between the four sub-populations in terms of the metabolism of glucose, lactate and several amino acids might play a role in this context. In bioreactor cultivations a two-fold higher lactate formation was observed for SP420 as compared to SP21, for instance.

The highest specific production rate of $10.5 \mathrm{pg} /$ (cell-day) was obtained for the sub-population SP95 resulting in a final antibody titer of $334 \mathrm{mg} / \mathrm{L}$. Considering longterm cultivation, cell specific productivity increased during first passages and was lost with ongoing subcultivation. Further cytometry analysis regarding intracellular productivity of examined CHO DP-12 cells revealed that serial subculturing resulted in accumulation of a subclone expressing only the light chain of the IL-8 antibody.

\section{Conclusions}

Serial subculturing over an extended period led to the selection of faster growing and $\mathrm{pH}$-shift permissive cells, thus resulting in higher viable cell densities, especially in uncontrolled shake flask cultivations. Furthermore, cells or rather sub-populations with distinct metabolic characteristics were enriched along the subculturing process. This indicated that a targeted experimental approach could be used e.g. to specifically select cells adapted to low glutamine concentrations and therefore, a reduced consumption rate. On the other hand, the observed loss of productivity shows that the selection pressure given by $200 \mathrm{nM}$ methotrexate and deprivation of hypoxanthine and thymidine could not prevent an increase of sub-populations expressing no or only incomplete (non-native, deficient) product. This problem could be caused by the vector design maybe used for the CHO DP-12 cells, which resulted in a non associated integration of the dihydrofolate reductase ( $\mathrm{dhfr}$ ) and anti-IL 8 sequences. Hence, it might be interesting to monitor the intracellular expression during clone selection or even seed-train development by flow cytometry.

\section{Acknowledgements}

The authors would like to thank Miltenyi Biotec $\mathrm{GmbH}$ for providing the MACSQuant ${ }^{\circledR}$ analyzer and consumables.

\section{Author details}

'Institute of Cell Culture Technology, Bielefeld University, Bielefeld, Germany. ${ }^{2}$ TeutoCell AG, Bielefeld, Germany.

Published: 22 November 2011 


\section{Reference}

1. Beckmann $T$, Thüte $T$, Heinrich $C$, Büntemeyer $H$, Noll $T$ : Proteomic and metabolomic characterization of CHO DP-12 cells with different high passages histories. Proc 22nd ESACT Meeting Vienna 2011.

doi:10.1186/1753-6561-5-S8-P29

Cite this article as: Heinrich et al:: Growth characterization of $\mathrm{CHO}$ DP-

12 cell lines with different high passage histories. BMC Proceedings 2011 5(Suppl 8):P29.

Submit your next manuscript to BioMed Central and take full advantage of:

- Convenient online submission

- Thorough peer review

- No space constraints or color figure charges

- Immediate publication on acceptance

- Inclusion in PubMed, CAS, Scopus and Google Scholar

- Research which is freely available for redistribution

Submit your manuscript at www.biomedcentral.com/submit 